\title{
DETERMINAÇÃO DAS CONCENTRAÇÕES DE ATIVIDADE DE 234U E 238U EM ÁGUAS SUBTERRÂNEAS DE TRÊS POÇOS PERFURADOS EM ROCHAS DA SUÍTE INTRUSIVA DE ITU (SP)
}

\author{
Francisca de Souza \\ Orientador: Dra. Leila Soares Marques (IAG-USP) \\ 102 p. - Dissertação (Mestrado) - Defesa 14.06.2006
}

\begin{abstract}
RESUMO. Foram determinadas as concentrações de atividades de 234U e 238U em águas subterrâneas extraídas de três poços perfurados em rochas na Suíte Intrusiva de Itu (SP), sendo dois deles localizados no Município de Salto (poços S e SY) e um em Itu (poço I). 0 período de amostragem iniciou em setembro de 2004 e terminou em dezembro de 2005, com o total de 12 coletas mensais em cada poço. Para as determinações foi utilizada a técnica da espectrometria alfa, associada ao método de diluição isotópica, que forneceu resultados com ótimos níveis de precisão, mostrada pela grande concordância dos resultados obtidos na análise de 23 duplicatas. As águas dos três poços apresentam um considerável enriquecimento de $234 \mathrm{U}$ em relação ao $238 \mathrm{U}$, indicando desequilíbrio radioativo significativo entre estes dois radioisótopos. No poço I as concentrações de atividade de $238 \mathrm{U}$ variaram de $(1,06 \pm 0,03)$ a $(2,1 \pm 0,2) \mathrm{mBq} / \mathrm{L}$ e as de $234 \mathrm{U}$ situaram-se entre $(3,1 \pm 0,2)$ e $(6,0 \pm 0,4) \mathrm{mBq} / \mathrm{L}$, enquanto as razões de atividades $234 \mathrm{U} / 238 \mathrm{U}$ não apresentaram variação significativa ao longo do período de amostragem, com média de $(2,8 \pm 0,1)$. As águas de $S$ são as que apresentaram as menores concentrações de urânio e as maiores variações nas concentrações de atividades de 238U, que variaram de $(0,26 \pm 0,02)$ a $(1,07 \pm 0,08) \mathrm{mBq} / \mathrm{L}$, e de $234 \mathrm{U}$, que se situaram entre $(1,8 \pm 0,1)$ e $(7,0 \pm 0,5) \mathrm{mBq} / \mathrm{L}$, como também nas razões de atividades 234U/238U, cuja variação foi de $(2,79 \pm 0,07)$ a $(8,1 \pm 0,3)$. No poço SY, as atividades de $238 \mathrm{U}$ variaram entre $(0,8 \pm 0,1)$ e $(4,2 \pm 0,3) \mathrm{mBq} / \mathrm{L}$, as de $234 \mathrm{U}$ entre $(14 \pm 1)$ e $(53 \pm 4) \mathrm{mBq} / \mathrm{L}$, e as razões $234 \mathrm{U} / 238 \mathrm{U}$ ficaram no intervalo de $(12,6 \pm 0,3)$ a $(18,3 \pm 0,4)$, com as maiores atividades de ambos os radioisótopos registradas nos meses de estiagem e as menores na época de chuva. A razão de atividades 234U/238U, que se manteve constante ao longo do período de amostragem, indica que em I há contribuição de água de chuva alimentando 0 aqüífero. 0 comportamento dessa razão, em função da concentração de urânio, mostrou processos de recarga bem mais complexos para S e SY, que apesar de próximos, apresentam comportamento muito diverso. As águas de S devem ter a contribuição de pelo menos 3 componentes de mistura (água meteórica, água do aqǘfero sedimentar pobre em urânio e água do granito fraturado). Em SY, além da água de chuva, parece haver uma contribuição devida a diferentes graus de lixiviação de U do granito fraturado, com solubilização preferencial de 234U, causada pelo estado oxidante destas águas. Considerando-se as águas dos três poços conjuntamente, verificou-se que a quantidade de sólidos totais dissolvidos apresentou variação entre $125 \mathrm{mg} / \mathrm{L}$ e $330 \mathrm{mg} / \mathrm{L}$, enquanto as concentrações de urânio variaram de 0,032 a 0,42 ng/g, as quais estão bem abaixo dos padrões estabelecidos para a sua ingestão, não representando nenhum risco à saúde humana.
\end{abstract}

ABSTRACT. Activity concentrations of 234U and 238U were determined in groundwater drawn from three deep wells drilled in rocks from Itu Intrusive Suite (SP), two located in Salto town (S and SY wells) and the other one in Itu (I well). Sampling was done from September, 2004 to December, 2005, and twelve samples of each well were collected monthly. For those determinations alpha spectrometry technique was used, providing high precision results, as shown by the very good agreement of the data obtained in the analyses of 23 duplicates. The waters from the three wells presented a considerable enrichment of $234 \mathrm{U}$ in relation to $238 \mathrm{U}$, indicating an important radioactive disequilibrium of these isotopes. In I well, the activity concentrations of $238 \mathrm{U}$ varied from (1.06 \pm 0.03$)$ to $(2.1 \pm 0.2) \mathrm{mBq} / \mathrm{L}$ and those of $234 \mathrm{U}$ spanned from $(3.1 \pm 0.2)$ to $(6.0 \pm 0.4) \mathrm{mBq} / \mathrm{L}$, whereas $234 \mathrm{U} / 238 \mathrm{U}$ activity ratios did not present significant variation, during the sampling time interval, presenting an average of $(2.8 \pm 0.1)$. The $S$ waters showed the lowest uranium concentrations and the largest diversity of $238 \mathrm{U}$ and $234 \mathrm{U}$ activity concentrations, which varied from $(0.26 \pm 0.02)$ to $(1.07 \pm 0.08) \mathrm{mBq} / \mathrm{L}$ and from $(1.8 \pm 0.1)$ to $(7.0 \pm 0.5) \mathrm{mBq} / \mathrm{L}$, respectively, and also presented variable $234 \mathrm{U} / 238 \mathrm{U}$ activity ratios, spanning from (2.79 \pm 0.07$)$ to $(8.1 \pm 0.3)$. In SY well, $238 \mathrm{U}$ activities varied between $(0.8 \pm 0.1)$ and $(4.2 \pm 0.3) \mathrm{mBq} / \mathrm{L}$ and those ones of $234 \mathrm{U}$ from (14 \pm 1$)$ to $(53 \pm 4)$ $\mathrm{mBq} / \mathrm{L}$, whereas $234 \mathrm{U} / 238 \mathrm{U}$ ratios fell in the interval from $(12.6 \pm 0.3)$ to $(18.3 \pm 0.4)$, with the highest activities of both radioisotopes registered during the dry season and the lowest ones in the rainy time period. The $234 \mathrm{U} / 238 \mathrm{U}$ activity ratios, which were invariable during sampling period of I well, indicated the contribution of rainfall to recharge the aquifer. The observed correlation between those ratios and uranium concentrations, for S and SY wells, showed complex and distinct recharging processes. The waters from $S$ have a contribution of at least three mixing components (meteoric water, groundwater from the sedimentary aquifer, probably very depleted in uranium, and groundwater from fractured granite). The waters from SY, besides a rainfall contribution, seem also to have a component related to leaching of uranium from the granite, with preferential solubilization of $234 \mathrm{U}$, since the aquifer is under oxidant condition. Considering the ensemble of waters from the three investigated wells, the total dissolved solids varied from to 125 to $330 \mathrm{mg} / \mathrm{L}$, whereas uranium concentrations spanned between $0.032 \mathrm{and} 0.42 \mathrm{ng} / \mathrm{g}$, indicating that their ingestions do not cause any risk to the health human being. 